\title{
Az EKÁER-ellenőrzések rendészeti jellege
}

\section{PAJOR Andrea ${ }^{1}$}

\begin{abstract}
A Nemzeti Adó- és Vámhivatal mint állami adó- és vámhatóság egy sajátos "Janus-arcú" szervezet, amelynek feladatellátásában keverednek a kormánytisztviselök hatáskörei a pénzügyőrök speciális jogállásából eredő hatásköreivel. Ennek egy tipikus megjelenési területe az Elektronikus Közúti Áruforgalom Ellenőrző Rendszerhez kapcsolódó kötelezettségek teljesítésének helyszíni vizsgálata. Ezek a vizsgálatok EKÁER-ellenőrzés néven kerültek be a szakzsargonba és ezzel összefüggésben a köznyelvbe is. Jelen tanulmányban arra mutatok rá, hogy a közúton végzett helyszíni ellenőrzés valójában egy rendészeti intézkedés, amely szükségszerü megelőző intézkedése az EKÁER-hez kapcsolódó adózói bejelentési kötelezettségek teljesitésére irányuló jogkövetési vizsgálatnak.
\end{abstract}

Kulcsszavak: pénzügyőri intézkedés, jogkövetési vizsgálat, hatáskör, Elektronikus Közúti Áruforgalom Ellenőrző Rendszer (EKÁER)

\section{Bevezetés}

A Nemzeti Adó- és Vámhivatal (a továbbiakban: NAV) olyan sajátos központi hivatal, amely a Nemzeti Adó- és Vámhivatalról szóló 2010. évi CXXII. törvény (a továbbiakban: NAV tv.) szerint államigazgatási és fegyveres rendvédelmi feladatokat is ellát. Tekintettel a NAV e kettős feladatrendszerére - ami részben abból fakad, hogy két korábbi központi államigazgatási szerv összevonása nyomán jött létre -, személyi állományának meghatározó részét kormánytisztviselók és a hivatásos állomány tagjai, azaz pénzügyőrök alkotják. ${ }^{2}$

A hivatásos szolgálati jogviszony egy olyan különleges közszolgálati jogviszony, amelyben a hivatásos állomány tagjai feladataikat szigorú függelmi rendben, életük és testi épségük kockáztatásával, valamint egyes alapjogaik korlátozásának elfogadásával teljesítik. A NAV alaptevékenységébe tartozó feladatok közül azokat, amelyek sajátos körülmények között végzett, az élet és testi épség kockáztatásával járó tevékenységnek minősülnek, kizárólag hivatásos szolgálati jogviszonyban állók láthatják el, az egyéb hatósági jellegú feladatokat pedig kormánytisztviselők végzik. Lényeges megkülönböztető ismérv a két jogviszony között a legitim „állami erőszak” alkalmazásának

\footnotetext{
PAJOR Andrea, mesteroktató, NKE RTK Vám- és Pénzügyőri Tanszék

Andrea PAJOR, Master Instructor, NUPS Faculty of Law Enforcement Department of Customs and Finance Guards https://orcid.org/0000-0003-4754-3654; pajor.andrea@uni-nke.hu

2 Szilvásy (2018) 255.
} 
lehetősége a pénzügyőrök esetében, tekintettel arra, hogy a hivatásos állomány tagjai intézkedések, kényszerítő eszközök alkalmazására jogosultak. ${ }^{3}$

Ezzel a megkülönböztető ismérvvel együtt járó „előnyök” a pénzügyőrök oldalán különösen az ellenőrzés területén bírnak jelentőséggel. Nézetem szerint a NAV létrehozásának hátterében is ez volt az egyik vezérlő gondolat, azaz ami a kormánytisztviselők eszköztárából hiányzik, azt a pénzügyőrök eszközrendszerével kell pótolni, és fordítva.

\section{Rendészet, rendvédelem}

Nem kerülhetem meg írásomban a rendvédelem és a rendészet fogalmának körüljárását, hiszen a tanulmány címe már jelez egy állásfoglalást a rendészet mellett, annak ellenére, hogy a NAV jogállásáról szóló törvény fegyveres rendvédelmi feladatokat is ellátó központi hivatalként határozza meg a NAV-ot.

Az említett két fogalom körül bizonytalanság tapasztalható a köznyelvben, a szakirodalomban, sőt a jogalkotás szintjén is.

„Rendészet vagy rendvédelem? Sem a szakirodalom, sem a rendészeti tételes jog nem tudott egyességre jutni a szóhasználatban. A vitában még az is felmerült, hogy vajon melyik igaz és melyik hamis, a rendészet vagy a rendvédelem?”4

Ha „civil” állampolgárként gondolkodunk el a rendészet és a rendvédelem fogalmáról, arra jutunk, hogy a két fogalom számunkra ugyanazt jelenti, szinonimaként használható. Körülbelül ugyanazt gondoljuk a fogalmak kapcsán: az állam törvényes rendjének megvédése akár kényszerítő eszközök alkalmazásával. Ha arra gondolunk, hogy kinek a feladata mindezt megtenni, e tekintetben az állampolgárok többségének a rendőrség mint szervezet jut eszébe.

A szakirodalomban „a rendészeti tevékenységet egyes esetekben pusztán a rendőrségi szervezet feladatellátására vonatkoztatják, más esetekben a szerzők rendkívül tág rendészetfogalmat használnak. Utóbbi értelemben a rendészet a közigazgatás azon szegmense, amely közbiztonságot szolgáltat a társadalom számára, illetve amelyik a jogellenes magatartásból eredő zavarokat a legitim fizikai erőszak monopóliumának birtokában hárítja el". 5

Balla Zoltán szerint a rendészetet a közfeladata (vagyis a biztonság védése) és az ehhez rendelt cselekvési rendszere (intézkedések, kényszerintézkedések, legitim kényszer, titkos eszközök alkalmazása) különbözteti meg a közigazgatás többi ágazatától. ${ }^{6}$ Ugyanebben a munkájában azt is megfogalmazta, hogy a rendészet egyik legtipikusabb jellemzője az intézményrendszere. Érvelése szerint ezt a struktúrát a közbiztonsághoz való kötődés ereje, minősége, valamint az ehhez rendelt hatáskörök, illetve a legitim erő-

\footnotetext{
Magasvári (2018) 40.

Finszter (2018) 22.

Finszter (2018) 21.

Balla (2017) 42.
} 
szak és a titkos eszközök alkalmazhatósága szempontjából öt alrendszerre oszthatjuk. Így megkülönböztethetjük egymástól a következőket:

- az elsődleges rendészeti szerv,

- a másodlagos rendészeti szervek,

- az egyes rendészeti feladatokat ellátó vegyes szervek,

- a törvényhozói hatalom rendészeti szerve, valamint

- a közhatalmi jogosítvánnyal nem rendelkező rendészeti jellegú egyéb szerveket. ${ }^{7}$

Ebben a csoportosításban a másodlagos rendészeti szervek közé sorolja a NAV pénzügyőri szervét arra alapítottan, hogy az intézkedések, kényszerintézkedések szerényebb eszköztárával rendelkezik a rendőrséghez képest.

Finszter Géza a már idézett tankönyvében a rendészeti igazgatást teljesítő közigazgatási hatóságok négy kategóriáját különíti el, ezek:

- a szúkebb értelemben felfogott rendészeti hatóságok,

- a rendvédelmi szervek,

- a rendészetet támogató hivatalok, központok és

- a járulékos, korlátozott hatáskörü helyi rendészeti hatóságok.

Értelmezése szerint a szúkebb értelemben felfogott rendészeti hatóságok azok, amelyek a hatáskörükbe utalt rendészeti feladatok teljesítéséhez szükséges legitim fizikai erőszak-monopólium teljes körével rendelkeznek. Ezek a következők:

- az általános rendészeti hatáskörű rendőrség,

- a speciális hatáskörü rendőrségek,

- civil nemzetbiztonsági szolgálatok,

- a pénzügyi igazgatás területén általános hatáskörrel felruházott pénzügyőrség,

- a büntetés-végrehajtással összefüggő különös rendészeti hatáskörrel rendelkező büntetés-végrehajtási testület. ${ }^{8}$

A kategorizálás eltérő mivolta ellenére a két szerző álláspontja abban megegyezik, hogy a rendészet „kebelébe” sorolja a pénzügyőrséget, amely ma a NAV hivatásos állományú tagjait jelenti.

A központi államigazgatási szervekről, valamint a kormány tagjai és az államtitkárok jogállásáról szóló 2010. évi XLIII. törvény a központi államigazgatási szervek közé sorolja a rendvédelmi szerveket.

A hivatkozott törvény szerint rendvédelmi szervek a következők:

a) a rendőrség,

b) a büntetés-végrehajtási szervezet,

c) a hivatásos katasztrófavédelmi szerv, és

d) a polgári nemzetbiztonsági szolgálatok. 
A felsorolásban a NAV rendvédelmi szervként nem szerepel, csak a már hivatkozott NAV tv. utal rá, hogy fegyveres rendvédelmi feladatokat is ellát. A NAV tv. részletesen tartalmazza a NAV szerteágazó feladatait, amelyeket adóigazgatási, vámigazgatási, jövedéki igazgatási, bűnüldözési és nyomozóhatósági, valamint rendészeti igazgatási feladatok körébe csoportosít. ${ }^{9}$

A NAV rendészeti és igazgatási jogkörében

a) végzi a külön jogszabály által hatáskörébe utalt szabálysértések felderítését és elbírálását,

b) ellátja a NAV nyomozó hatósága által elrendelt, a büntetőeljárással összefüggésben a jogszabályban meghatározott személyi kört érintő személyi védelmi feladatokat,

c) végzi meghatározott körben anyagi javak, értékek őrzését, kísérését,

d) végzi az elfogott, előállított, őrizetbe vett, valamint fogva tartott személyek őrzését, kísérését,

e) jogszabályban meghatározott ellenőrzési kötelezettségeinek és jogosultságainak végrehajtása egyik formájaként mozgó egységekkel végzi Magyarország területén - az EU külső határán működő határátkelőhelyek kivételével - a mélységi ellenőrzési tevékenységet,

f) végzi a külön jogszabályban meghatározott rendvédelmi, igazgatási feladatokat. $^{10}$

Ha áttekintjük a NAV jogállását, szervezetét érintő alapvető jogszabályokat - az eddig említetteken túl még a rendvédelmi feladatokat ellátó szervek hivatásos állományának szolgálati jogviszonyáról szóló törvényt ${ }^{11}$ is - arra jutunk, hogy a jogalkotó is kvázi szinonimaként használja a két fogalmat.

A rendvédelem kifejezés kapcsán azonban az is leszögezhető, hogy mint szakkifejezést a közigazgatás, illetve a rendészettudomány művelőinek nagy többsége elutasítja. Ezzel egyidejűleg tényként kell rögzíteni, hogy Magyarország Alaptörvénye használja a rendvédelem szót ${ }^{12}$ és ezzel normatív értelemben alkotmányosan legalizálja, ${ }^{13}$ annak ellenére, hogy egyébként nem rendelkezik sem rendészeti, sem pedig rendvédelmi szervekről.

Annak érdekében, hogy állást foglaljunk, és ezzel átlendüljünk a rendészet-rendvédelem problémakörén - tekintve, hogy az írásom témája a NAV által végzett EKÁERellenőrzések rendészeti jellege - megítélésem szerint érdemes a NAV törvény általi feladat-meghatározásból kiindulni.

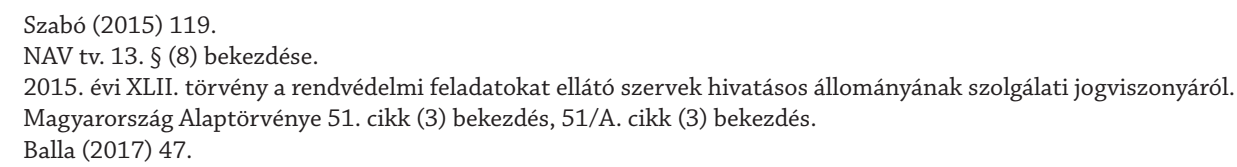


Ennek tanulmányozása azt támasztja alá, hogy a NAV:

- rendészeti feladatot lát el azzal, hogy a társadalom védelmét a pénzügyi igazgatás területén jelentkező jogellenes magatartások megelőzésével, megszakításával és felderítésével tölti be;

- rendészeti funkciókat gyakorol azzal, hogy a pénzügyi igazgatással összefüggő feladatait őrködéssel, információszerzéssel és a legitim fizikai erőszak alkalmazásával teljesíti;

- nyomozóhatósági jogkörben felderítést és nyomozást folytat a hatáskörébe utalt büncselekmények gyanúja esetén.

Összefoglalva: „[A] NAV olyan rendvédelmi feladatokat teljesítő kormányhivatal, amelyik a pénzügyi igazgatáshoz kapcsolódó különös hatáskörében rendészeti igazgatást teljesít."14

\section{Az Elektronikus Közúti Áruforgalom Ellenőrző Rendszer (EKÁER)}

Tovább közelítve a címben meghatározott témához, az alábbiakban elsőként az Elektronikus Közúti Áruforgalom Ellenőrző Rendszer (EKÁER) mibenlétét kell megvilágítanom röviden.

$\mathrm{Az}$ adóhatóság ellenőrzési gyakorlata azt mutatta, hogy általános forgalmi adó (a továbbiakban: áfa) tekintetében a csalárd adózói magatartások leggyakrabban a teljesen fiktív vagy nem az okmányokon szerepeltetett adatoknak megfelelő közösségi áruszállításokhoz, illetve az eltűnő - termékbeszerzés utáni áfafizetési kötelezettségüket nem teljesítő - kereskedőkhöz kapcsolhatók. A visszaéléseket leggyakrabban ömlesztett, egyedileg nem beazonosítható (nem címkézhető, jelölhető stb.), de nagy mennyiségben fogyasztott/felhasznált termékek tagállamok közti (körbe) utaztatásával követik el, kihasználva mindehhez az uniós normákban rögzített tagállami adómentes értékesítés lehetőségét. További probléma volt, hogy a termékértékesítéshez, termékbeszerzéshez köthető árumozgásokkal összefüggő adókötelezettségek teljesítésének ellenőrzéséhez a hatóságoknak pusztán olyan információk álltak a rendelkezésére, amelyekkel az árumozgások kizárólag utólagos ellenőrzés keretében voltak vizsgálhatók. Nehézséget jelentett az is, hogy a nemzetközi szállítást alátámasztó papíralapú okmányokból (CMR-okmányok) az adózók - annak szigorú számadási kötelezettsége hiányában - tetszóleges számú példányt állíthatnak ki. ${ }^{15}$

Figyelemmel a fentiekre korábban számos, a tagállamokat érintő kísérlet történt az áfakikerülés megelőzése, illetve a csalások felderítése érdekében. A legtöbb ilyen jellegú intézkedés azonban - adminisztratív voltának köszönhetően - nem hozta a várt gazdaságfehérítő eredményeket. A csalárd gazdálkodókkal szembeni hatékonyabb fellépés kulcsa tehát mindenképpen egy olyan módszer kialakítása kellett hogy legyen,

\footnotetext{
4 Finszter (2018) 266.

15 Mihics (2015) 3.
} 
amellyel az ellenőrző hatóságok számára a gazdasági események már azok tényleges megvalósulásakor követhetővé válnak, és a rendszer adatainak felhasználásával az áfaköteles ügyletek utólag is rekonstruálhatók.

Erre tekintettel került kidolgozásra az EKÁER, amely elsősorban az áfára elkövetett csalások visszaszorítása érdekében 2015. január 1-jétől került bevezetésre az adózás rendjéről szóló 2003. évi XCII. törvénnyel (a továbbiakban: régi Art.).

Jelenleg - részben a régi Art. újrakodifikálásának eredményeként - az EKÁER jogi szabályozása többlépcsős:

- törvényi szinten meghatározott a termékek közúti fuvarozásával kapcsolatos bejelentési kötelezettség, a bejelentendő adatok köre, a kockázati biztosíték nyújtására vonatkozó kötelezettség, ${ }^{16}$ továbbá a nem teljesítéssel kapcsolatos szankciók, intézkedések; ${ }^{17}$

- a fuvarozott termék ellenőrzésére vonatkozó szabályokat tartalmaz az adóigazgatási eljárás részletszabályairól szóló 465/2017. (XII. 28.) Korm. rendelet (a továbbiakban: kormányrendelet); és

- miniszteri rendeletben szabályozták az EKÁER múködésével kapcsolatos részletszabályokat, valamint a kockázatos termékek körét. ${ }^{18}$

Az előzőekben hivatkozott jogi szabályozás alapján jött létre és múködik tehát az EKÁER, amely egy komplex árumozgás-ellenőrző rendszer. Lényegét tekintve a közösségi termékértékesítéssel, illetve beszerzéssel, valamint az első belföldi áfaköteles termékértékesítéssel összefüggő áruszállítások e-útdíj kamerahálózat segítségével történő nyomon követését biztosítja. A müködése során elektronikusan - elemezhető formában - keletkező fuvarozási adatok olyan kockázatelemzést tesznek lehetővé, amely alapján akár valós idejű (a gazdasági eseményekkel egyidejúleg végzett), akár utólagos adóhatósági ellenőrzések végezhetők a kiemelt kockázatokra tekintettel.

$\mathrm{Az}$ új rendszer múködésének legfontosabb eleme, hogy 2015. január 1-jétől útdíjkötelessé vált a 3,5 tonna vagy annál nagyobb össztömegű gépjármű által végzett közúti fuvarozás, és annak megkezdése előtt a fuvarozásért felelős személynek vagy gazdasági társaságnak a tervezett szállítást be kell jelentenie az adóhivatalnál, és úgynevezett EKÁER-számot ${ }^{19}$ kell igényelnie. A jogszabályban meghatározott adóalanyi kör kizárólag érvényes EKÁER-számmal végezhet szállítási tevékenységet. Ide tartozik az Európai Unió más tagállamaiból Magyarországra irányuló termékértékesítés, valamint a Magyarországról az Európai Unió tagállamaiba irányuló termékértékesítés vagy egyéb célú kivitel, illetve a belföldre történő behozatal, ha nem közvetlenül a végfelhasználó részére történik, és a Magyarországra történő első beszállítás is, ha az áru áfa-

16 Régi Art. 22/E. §; az adózás rendjéről szóló 2017. évi CL. törvény (a továbbiakban: új Art.) 113. §.

17 Régi Art. 172. § (19a)-(19b) bekezdései, 173. §, 173/B. §; új Art. 226. § (2)-(3) bekezdései, 240. §, 244. §.

18 Az Elektronikus Közúti Áruforgalom Ellenőrző Rendszer működéséről szóló 5/2015. (II. 27.) NGM rendelet, valamint az Elektronikus Közúti Áruforgalom Ellenőrző Rendszer müködésével összefüggésben a kockázatos termékek meghatározásáról szóló 51/2014. (XII. 31.) NGM rendelet.

19 EKÁER-szám: az Elektronikus Közúti Áruforgalom Ellenőrző Rendszer által a termék közúti fuvarozásának bejelentését követően automatikusan képzett azonosító szám, amely egy adott termékegységet azonosít. 
köteles. Az EU területén kívülre irányuló exporthoz, illetve az onnan bejövő importhoz kapcsolódó szállítmányozási tevékenység is engedélyköteles, tehát ezek a szabályok vonatkoznak ezekre a tevékenységekre is. ${ }^{20}$

A rendszer múködésének nélkülözhetetlen eleme az országos kamerahálózat, melynek müködési szabályait a 2013. évi LXVII. törvény ${ }^{21}$ határozza meg. 2015. január 1-jétől a köznyelvben HU-GO rendszerként ismert e-útdíj kamerahálózat által begyújtött digitális forgalmi információkat a NAV jogosult átvenni és munkájában felhasználni. A közúti forgalmi utat ellenőrző kihelyezett kamerák segítségével a szállítmányok mozgása, a teljes belföldi közúti hálózatban nyomon követhető és az összegyưjtött adatok egybevethetők a NAV rendelkezésére álló adatokkal, így az adózók által teljesített EKÁER bejelentéseken alapuló információkkal is. A rendszer kiegészül továbbá az adózók által nyújtott pénzügyi garanciarendszerrel. Ennek összegét az EKÁER bejelentésre kötelezett vállalkozás előző 45 napos forgalmi adatai alapján határozzák meg, hasonlóan a jövedéki adók biztosítéki rendszeréhez. ${ }^{22}$

Ahogy arra előzőleg már utaltam, az adatok (feladó adatai, felrakodás címe, címzett adatai, kirakodás címe, szállított áru megnevezése, tömege, termék közúti fuvarozásának indoka, fuvarozáshoz használt gépjármű forgalmi rendszáma stb.), az EKÁER-ben elsősorban az adózók (a fuvarozott áru viszonylatában: feladó, címzett) kötelező bejelentései nyomán keletkeznek, illetve a bejelentés elmulasztása esetén - ha ezt a NAV ellenőrzése során észleli - az adatokat az ellenőrzést végző szervezeti egység rögzíti az EKÁER-ben.

\section{A rendészeti jelleg megnyilvánulása az EKÁER-ellenőrzések során}

Az alábbiakban rátérek annak kifejtésére, miért is gondolom azt, hogy az EKÁER-ellenőrzések során nem kis jelentősége van a NAV rendészeti tevékenységének.

Elsőként azt szükséges rögzíteni, hogy az EKÁER-bejelentések teljesítését, illetve valóságtartalmának kontrollálását érintő vizsgálatok az árumozgások három fő területén merülnek fel leggyakrabban. Az első az áru közúti fuvarozásának folyamatához, a második az elfuvarozott áru kirakodásához, a harmadik pedig a kirakodási címre leszállított áru további sorsához kapcsolódik. Ennélfogva az EKÁER adatait főként az alábbi ellenőrzési típusok esetében vizsgálják:

- közúton végzett ellenőrzés, amely álláspontom szerint a NAV rendészeti jogkörében végzett intézkedést, majd az adóigazgatási rendtartásról szóló 2017. évi CLI. törvény (a továbbiakban: Air.) szerinti jogkövetési vizsgálatot jelent;

- belföldi kirakodási címen végzett ellenőrzés, amely az Air. szerinti adatgyưjtésre vagy egyes adókötelezettségek teljesítésére irányuló jogkövetési vizsgálat;

2013. évi LXVII. törvény az autópályák, autóutak és fôutak használatáért fizetendő, megtett úttal arányos díjról.

22 Szilovics (2019) 104. 
- utólag végzett ellenőrzés, amely lehet a bejelentések teljesítésének vizsgálata akár áfa adónemre lefolytatott Air. szerinti adóellenőrzés keretében, de lehet akár egyes adókötelezettségek teljesítésére, illetve egyes gazdasági események valódiságának vizsgálatára irányuló jogkövetési vizsgálat is, az ellenőrzés irányultságától függően.

A NAV belső szabályozása szerint a megyei (fővárosi) adó- és vámigazgatóságoknak az illetékességi területükön biztosítaniuk kell, hogy minden nap - kivéve a nehézgépjármúvek közlekedésének korlátozásával érintett időszakban - 0-24 órában végezzenek EKÁER-ellenőrzéseket a közutakon. A közúti EKÁER-ellenőrzést az ellenőrző egységek elsődlegesen járőrirányítás vagy járőrkoordináció alapján, ezenkívül szúrópróbaszerűen vagy előzetes vezetői feladatmeghatározás alapján végzik.

A NAV rendelkezésére álló humán erőforrás minél hatékonyabb kihasználása és az ellenőrzési tevékenység hatékonyságának növelése érdekében - ha a gépjármúforgalom mértéke és az ellenőrző egységek ellenőrzési kapacitása engedi - a már megállított gépjárművek több szempontból történő ellenőrzését is el kell végezni (például pihenőidő vizsgálata, a közúti közlekedésről szóló 1988. évi I. törvény alapján végzett egyéb ellenőrzés, árueredet-vizsgálat stb.).

Fenti előírásra tekintettel az EKÁER-rel összefüggő bejelentési kötelezettség ellenőrzése az esetek nagy részében közúti ellenőrzéssel kezdődik, azzal, hogy a közúti ellenőrzést jellemzően még nem a bejelentésre kötelezett adózónál folytatják le, így azt - jogszabálysértés esetén - általában követi egy újabb, már a bejelentésre kötelezett adózónál lefolytatott adóhatósági ellenőrzés (vagy adóellenőrzés, vagy jogkövetési vizsgálat az Air. szabályai szerint). Következik ez abból, hogy a jogszabály az adókötelezettség teljesítését (jelen esetben az EKÁER bejelentési kötelezettséget) az adózó (jelen esetben a címzett, illetve a feladó) számára írja elő. A fuvarozó nem felel az EKÁER bejelentési kötelezettség teljesítésért. Az esetek többségében maga a fuvarozás nem a címzett, illetve a feladó fuvareszközével történik, hanem a felek - megállapodásuk szerint - fuvarozó céget vesznek igénybe az áru elszállítására. Ebből adódóan a megállított gépjármű vezetőjével szemben legfeljebb adatgyűjtésre irányuló jogkövetési vizsgálat kezdhető meg, arra tekintettel, hogy a kormányrendelet jogkövetési vizsgálat megkezdését akkor is lehetővé teszi, ha az adózó alkalmazottja van jelen. Fő szabály szerint a kormányrendelet ugyanis azt mondja ki, hogy a helyszíni ellenőrzést az adóhatóság csak akkor kezdheti meg, ha az adózó vagy annak képviselője, meghatalmazottja, ezek hiányában két hatósági tanú jelen van.

Abban az esetben, ha a gépjármú vezetője valamely adózó (feladó vagy címzett) alkalmazottja, vele szemben a jogkövetési vizsgálat megkezdhető a kormányrendelet ismertetett fő szabálya szerint.

Megítélésem szerint a gépjármű megállítását követően a gépkocsivezetőtől az ellenőrzést végző pénzügyőr elsőként felvilágosítást kérhet intézkedés keretében. Majd ettől függően, az ebből szerzett információ alapján kezdeményezhet Air. szerinti jogkövetési vizsgálatot. Ezt a vélekedésemet alátámasztja a belső szabályozó is, hiszen 
kimondja, hogy a közúton végzett ellenőrzések során az ellenőrző egységnek minden esetben nyilatkoztatnia kell a gépjárművezetőt arról, hogy szállít-e, birtokol-e jövedéki terméket, illetve a szállított árura, a szállítás útirányára és céljára vonatkozóan. Amenynyiben a közúti ellenőrzéssel érintett jármű EKÁER szempontjából történő ellenőrzés alá vonása indokolt, úgy az ellenőrzést az ellenőrző egység az Air., az új Art. és a kormányrendelet rendelkezései alapján kezdi meg.

\section{A pénzügyőrök intézkedési lehetőségei}

A tanulmány elején - a jogi szabályozás elemzésével - levezettem, hogy a pénzügyőrök szolgálatuk teljesítése során rendészeti feladatokat látnak el, ebből következően tevékenységük során jogosultak - a rendészet más szerveihez hasonlóan - a jogszabályban meghatározott egyes intézkedések foganatosítására. ${ }^{23}$

A hatósági intézkedés fogalmi mibenlétét illetően rögzíthető, hogy a hatósági döntés fogalmán kívül eső hatósági aktusnak minősül. Jellemzően a hatóság nevében hatósági intézkedés tételére jogosult személy szóbeli aktusa, amelyet a jogalany köteles azonnal teljesíteni. ${ }^{24}$ Általában nincs ellene közvetlen jogorvoslati lehetőség, de a rendészeti szervek intézkedése esetén panasszal lehet élni, azzal, hogy a panasz nem bír halasztó hatállyal, tehát nem zárja ki az intézkedés végrehajtását.

Tekintve, hogy az intézkedési jogosultság kizárólag a NAV hivatásos állományú tagját illeti meg, fontos, hogy az intézkedés alá vont személy tudata átfogja az intézkedő pénzügyőri mivoltát. Ebben kiemelt jelentősége van az egyenruhának, amely szintén kizárólag a pénzügyőri állomány privilégiuma. Az intézkedések alkalmával a pénzügyőrt az egyenruhája és az azon elhelyezett azonosítószáma, vagy ha nem visel egyenruhát, akkor a szolgálati igazolványa és a szolgálati jelvénye igazolja. A jogszabályi előírások végrehajtását szolgáló intézkedésnek alapvetően mindenki köteles magát alávetni és a pénzügyőr utasításának engedelmeskedni. Az intézkedés során annak jogszerüsége nem vonható kétségbe, kivéve ha a jogszerűtlenség mérlegelés nélkül, kétséget kizáróan megállapítható.

A pénzügyőr jogszerú intézkedésének való ellenszegülés esetén a NAV tv.-ben meghatározott intézkedések és kényszerítő eszközök alkalmazhatók. ${ }^{25}$

Azt, hogy milyen intézkedést tehet a pénzügyőr, a NAV tv. III. fejezete határozza meg, amely jelenleg tizenegy különböző intézkedést nevesít (felvilágosítás kérése; igazoltatás; ruházat, csomag és jármű átvizsgálása; elfogás és előállítás; intézkedés magánlakásban és közterületnek nem minősülő egyéb helyen; a helyszín biztosítása; egyéb pénzügyőri intézkedések; képfelvétel, hangfelvétel, kép- és hangfelvétel készítése; létesítmény őrzés-védelmi intézkedés; rejtett ellenőrzés elrendelése; a Schengeni

Erdős (2018) 138.

Lapsánszky (2019) 485-486.

NAV tv. 35/C. §. 
Információs Rendszerben elhelyezett rejtett ellenőrzésre irányuló figyelmeztető jelzés végrehajtása). ${ }^{26}$

A felsoroltak azonban ténylegesen nemcsak tizenegy intézkedést fednek le, ugyanis az egyéb pénzügyőri intézkedések cím alatt további öt, egymástól egyértelműen elkülöníthető intézkedés található:

- közúti ellenőrzés,

- beszállításra kötelezés,

- lefoglalás,

- tartozásvizsgálat,

- orvosi vizsgálatra kötelezés. ${ }^{27}$

Ez utóbbiak közül - a tanulmány témáját tekintve - a már említett közúti ellenőrzés bír különös jelentőséggel, miszerint a pénzügyőr a szolgálati feladatok ellátása céljából közutakon, közforgalom számára megnyitott területen személyeket, jármúveket - a közúti közlekedés rendjéről szóló jogszabályban meghatározott jelzések alkalmazásával - megállíthat.

Adott esetben jelentőséggel bírhat a beszállításra kötelezés is, amely szerint a pénzügyőr a vám- és jövedéki jogszabályok, továbbá a NAV szerveinek feladatát meghatározó egyéb jogszabályok megsértésének észlelése, gyanúja esetén elrendelheti az ellenőrzés tárgyát képező dolog hivatalos helyre történő azonnali beszállítását, amennyiben az ellenőrzés biztonságos és eredményes lefolytatásához az ellenőrzés helyszínén a feltételek nem adottak, vagy az ellenőrzés végrehajtása mások személyi, illetve vagyonbiztonságát veszélyezteti. A dolog birtokosa köteles az elrendelésnek eleget tenni, és amennyiben vele szemben az eljárás során jogsértést nem állapítanak meg, kérheti igazolt költségeinek megtérítését. Ugyancsak előfordulhat az EKÁER-kötelezettség ellenőrzése során, hogy bűncselekmény gyanúja merül fel, ez esetben a pénzügyőr halasztást nem tűrő esetben jogosult lefoglalás elrendelésére, és a hatáskörrel és illetékességgel rendelkező nyomozó hatóság felé a szükséges intézkedéseket megteszi.

Előzőek mellett a pénzügyőrök kényszerítő eszközök alkalmazására is jogosultak (testi kényszer; bilincs; vegyi eszköz, sokkoló eszköz, rendőrbot, illetve más eszköz alkalmazása; lőfegyverhasználat; szolgálati kutya alkalmazása; útzár telepítése, megállásra kényszerítés). Az áruszállítás ellenőrzése tekintetében adott esetben nem kizárt, hogy akár útzár telepítésére vagy megállásra kényszerítésre is szükség lehet.

A kényszerítő eszköz fogalmát rendészeti szempontból megközelítve úgy lehet meghatározni, hogy az „a közrend, közbiztonság fenntartása érdekében eljáró szervek által jogszabályban meghatározott módon alkalmazható olyan hatósági aktus, amely szükségszerűen, az intézkedés törvényes céljának megvalósulása érdekében az alapvető emberi jogok (így különösen az emberi méltóság, személyes szabadság, testi épség, végső esetben az élethez füződő jogok) korlátozásával, illetve sérelmével jár" ${ }^{28}$

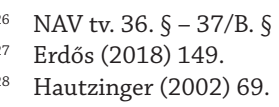


Ezzel összefüggésben kiemelést érdemel a NAV törvény indokolása, amely rögzíti, hogy „a pénzügyőri intézkedés eredményessége nem függhet az érintett belátásától, ezért szükség esetén az kikényszeríthető. A kikényszerítés többnyire a személyi szabadság átmeneti korlátozásával jár”. ${ }^{29}$

Az előzőek alapján látható, hogy a pénzügyőrök által alkalmazható intézkedések és kényszerítőeszközök rendkívüli többletjogosultságot jelentenek a kormánytisztviselők jogosultságaihoz képest.

\section{Összegzés}

Ha visszagondolunk az EKÁER létrehozásának célja tekintetében a bevezetőben rögzítettekre, jelesül arra, hogy magát a rendszert az áfacsalások megelőzése, felszámolása érdekében alakították ki, könnyen belátható, hogy a kormánytisztviselők szerényebb eszközeivel és jogosultságaival a fuvarozásban érintett gépjármű megállítására sem lenne lehetőség, arról nem beszélve, hogy a kormánytisztviselőnek nincs joga igazoltatásra, nincs joga ellenszegülés esetén kényszerítő intézkedések alkalmazására, bűncselekmény gyanúja esetén nincs joga megtenni a halaszthatatlan intézkedéseket.

Ezek azok a tények és körülmények, amelyekkel - meglátásom szerint - igazolható, hogy a NAV hatósági jogalkalmazó munkájában EKÁER-ellenőrzésnek ${ }^{30}$ titulált tevékenységben jelentős hányadot képvisel a rendészeti tevékenység. Megjegyzem ugyanakkor, némiképp ellentmondásba kerülve az általam választott címmel, hogy EKÁER-ellenőrzés jogilag nem létezik, csak a NAV mint állami adó- és vámhatóság szakzsargonában alakult ki ez a fogalom. Valójában az EKÁER-hez kapcsolódó kötelezettségek teljesítésének vizsgálatára irányuló ellenőrzésről beszélhetünk, ami az adóeljárási jogszabály szerint történhet jogkövetési vizsgálat keretében, de történhet utólag is, adóellenőrzés keretében. Az EKÁER-hez kapcsolódó bejelentési kötelezettségek jogkövetési vizsgálata azonban legtöbbször helyszínen történik, azaz közúton (áruszállítás közben), illetve a belföldi kirakodási helyszínen. A helyszíni vizsgálatokon belül pedig a legtöbb közúton történik (az ellenőrző egységek 2018-ban 190273 gépjármü ellenőrzését végezték $\mathrm{el}^{31}$ ), amelyek során elsőként egy pénzügyőri intézkedéssel meg kell állítani a gépjárművet, felvilágosítást kell kérni a gépjármű vezetőjétől a szállít-

\footnotetext{
NAV tv. 38-39. §-aihoz füzött indoklás.

30 A Nemzeti Adó- és Vámhivatal vezetője által kiadott 1131/2018/VEZ eljárási rend az Elektronikus Közúti Áruforgalom Ellenőrző Rendszerrel kapcsolatos feladatok végrehajtásáról 2.2. Értelmező rendelkezések j) pont: EKÁER ellenôrzés: az igazgatóságok által az adóigazgatási rendtartásról szóló 2017. évi CLI. törvény (a továbbiakban Air.) 91. §-ban rögzített vizsgálat során végzett azon tevékenysége, amely - az Art-ban és a miniszteri rendeletben, továbbá az Elektronikus Közúti Áruforgalom Ellenőrző Rendszer működésével összefüggésben a kockázatos termékek meghatározásáról szóló 51/2014. (XII. 31.) NGM rendeletben meghatározott - EKÁER-bejelentéssel és az azzal összefüggő kötelezettségekkel kapcsolatos előírások megtartásának vizsgálatára irányul, ide nem értve a szakrendszerekben szereplő adatok alapján végzett kockázatelemzéssel kapcsolatos tevékenységeket.

31 NAV évkönyv 2018. Tények, információk a Nemzeti Adó- és Vámhivatal szervezetérôl és annak 2018. évi tevékenységérôl (2019).
} 
mányról, az útirányról stb., és csak ezt követően „fordulhat át” a vizsgálat az Air. szerinti ${ }^{32}$ jogkövetési vizsgálattá, amennyiben annak jogszabályi feltételei fennállnak.

\section{IRODALOMJEGYZÉK}

Balla Zoltán (2017): A rendészet alapjai és egyes ágazatai. Budapest, Dialóg Campus Kiadó.

Erdős Ákos (2018): A pénzügyőri intézkedésekről. In Erdős Ákos szerk.: Integrált pénzügyőri ismeretek I. Kezdő pénzügyőrök kézikönyve. Budapest, Magyar Rendészettudományi Társaság Vám- és Pénzügyőri Tagozata. 138-155.

Finszter Géza (2018): Rendészettan. Budapest, Dialóg Campus Kiadó.

Hautzinger Zoltán (2002): A rendészeti kényszerítő eszközök alkalmazásának alapelvei. In: Tanulmányok a „Határörség és rendészet” címü tudományos konferenciáról Pécsi Határör Tudományos Közlemények I. Konferencia helye, ideje: Pécs, Magyarország, 2002. 06. 20. 69-76. Forrás: www.pecshor. hu/periodika/2002/hautzinger.pdf (2019. 09. 30.)

Lapsánszky András (2019): A hatósági ellenőrzés. In Patyi András szerk.: A közigazgatási hatósági eljárásjog jogintézményei. Budapest, Dialóg Campus Kiadó. 433-488.

Magasvári Adrienn (2018): A Nemzeti Adó- és Vámhivatal szerepe, szervezete, feladatai, személyi állománya. In Erdős Ákos szerk.: Integrált pénzügyőri ismeretek I. Kezdő pénzügyőrök kézikönyve. Budapest, Magyar Rendészettudományi Társaság Vám- és Pénzügyőri Tagozata. 25-43.

Mihics Henrik (2015): Az EKAER-rel kapcsolatos legfontosabb tudnivalók. Adóvilág, 19. évf. 1-2 sz. 3-13.

Szabó Andrea (2015): A magyar pénzügyőr képzés intézményi kereteinek fejlődése. Rendvédelem-történeti Füzetek, 25. évf. 43-46. sz. 117-126. DOI: https://doi.org/10.31627/RTF.XXV.2015.43-4445-46N.117-126P

Szilovics Csaba (2019): Az adócsalás elleni küzdelem új eszközéről. Büntetőjogi Szemle, 8. évf. 1. sz. 102-107.

Szilvásy György Péter (2018): Néhány megjegyzés a pénzügyőrök szolgálati jogviszonya és az alapjogi korlátozások kapcsolatáról. In Czene-Polgár Viktória - Zsámbokyné Ficskovszky Ágnes szerk.: Innováció, elektronizáció, tudásmenedzsment tanulmánykötet. Budapest, Magyar Rendészettudományi Társaság Vám- és Pénzügyőri Tagozata. 255-267.

\section{Jogforrások}

1988. évi I. törvény a közúti közlekedésről

2003. évi XCII. törvény az adózás rendjéről

2010. évi CXXII. törvény a Nemzeti Adó- és Vámhivatalról

32 Air. 91. § [Jogkövetési vizsgálat].

(1) Az adóhatóság jogkövetési vizsgálat keretében a bevallási időszak lezárását megelőzően is

a) ellenőrizheti, hogy az adózó eleget tett-e a törvényekben előírt egyes adókötelezettségeinek, azokat határidőben, illetve az adó megállapítására, bevallására és megfizetésére alkalmas módon teljesíti-e;

b) adatokat gyưjithet a nyilvántartásában és az adózó nyilvántartásában, bevallásában szereplő adatok, tények, körülmények valóságtartalmának, illetve ezek hitelességének megállapítása érdekében;

c) vizsgálhatja a gazdasági események valódiságát;

d) adatokat gyűjithet az ellenőrzési tevékenysége támogatása érdekében, így különösen becslési adatbázis létrehozásához, karbantartásához.

(2) * Az adóhatóság az állami adó- és vámhatóság nyomozó hatósági hatáskörrel felruházott szerve által feltárt adatok és bizonyítékok alapján büncselekmény elkövetési értékének megállapítása céljából is vizsgálhatja gazdasági események valódiságát jogkövetési vizsgálat keretében. 
2010. évi XLIII. törvény a központi államigazgatási szervekről, valamint a Kormány tagjai és az államtitkárok jogállásáról

2013. évi LXVII. törvény az autópályák, autóutak és főutak használatáért fizetendő, megtett úttal arányos díjról

2015. évi XLII. törvény a rendvédelmi feladatokat ellátó szervek hivatásos állományának szolgálati jogviszonyáról

2017. évi CL. törvény az adózás rendjéről

2017. évi CLI. törvény az adóigazgatási rendtartásról

465/2017. (XII. 28.) Korm. rendelet az adóigazgatási eljárás részletszabályairól

5/2015. (II. 27.) NGM rendelet az Elektronikus Közúti Áruforgalom Ellenőrző Rendszer müködéséről

51/2014. (XII. 31.) NGM rendelet az Elektronikus Közúti Áruforgalom Ellenőrző Rendszer múködésével összefüggésben a kockázatos termékek meghatározásáról

A Nemzeti Adó- és Vámhivatal vezetője által kiadott 1131/2018/VEZ eljárási rend az Elektronikus Közúti Áruforgalom Ellenőrző Rendszerrel kapcsolatos feladatok végrehajtásáról

Magyarország Alaptörvénye

NAV évkönyv 2018. Tények, információk a Nemzeti Adó- és Vámhivatal szervezetéröl és annak 2018. évi tevékenységéröl (2019). Budapest. Forrás: www.nav.gov.hu/data/cms496584/NAV_evkonyv_2018. pdf (2019. 12. 01.)

\title{
ABSTRACT
}

\section{The Law Enforcement Nature of EPRTCS Inspections}

\author{
PAJOR Andrea
}

The National Tax and Customs Administration, as a state tax and customs authority, is a special "Janus-faced" organisation; in the performance of duties, the competences of government officials intermingle with those based on the special status of finance guards. A typical area for this is the on-the-spot verification of compliance with obligations related to Electronic Public Road Transport Control System. These studies have been introduced into the jargon and in the common language under the name EPRTCS inspection. In this study, I point out that on-the-spot checks on roads are in fact a law enforcement measure that is a necessary preventive action for the compliance audit of taxpayers' reporting obligations under the EPRTCS system.

Keywords: actions taken by the finance guards, compliance audit, competence, Electronic Public Road Transport Control System (EKAER) 